\title{
STUDIES ON A NEW ANTIBIOTIC M-92 PRODUCED BY MICROMONOSPORA \\ II. ISOLATION AND PHYSICOCHEMICAL PROPERTIES OF M-92 AND ITS COMPONENTS
}

\author{
Kato Tani and Tetsuo Takaishi \\ Microbiological Research Laboratory, Tanabe Seiyaku Co., Ltd., \\ Toda, Saitama, Japan \\ (Received for publication July 6, 1982)
}

\begin{abstract}
A new antibiotic complex, M-92 was isolated from the whole fermentation broth of Micromonospora verruculosa MCRL 0404. The whole broth was mixed with talc and filtered. The filter cake thus obtained was extracted with acidic methanol to give a crude powder of M-92 complex, which was then separated into A (acidic) and $\mathrm{N}$ (neutral or weakly acidic) groups. The A group components are soluble in alkaline water $(\mathrm{pH} 8.5)$, while the $\mathrm{N}$ group components are not. These components were further separated into six major components designated VA-2, BA-4, BA-5, BN-1, BN-2 and $\mathrm{BN}-3$ by silica gel column chromatography. Components with the letter "V" are reddish violet and those with "B" are blue.

The IR and UV spectra of these components suggest that their chromophores may be the same or very closely related to one another. The molecular formula of BN-3 was determined to be $\mathrm{C}_{29} \mathrm{H}_{23} \mathrm{NO}_{9}$ by mass spectrometry. The results of various spectroscopies on $\mathrm{BN}-3$ suggest that M-92 components consisted of chromophores in which juglone (5-hydroxynaphthoquinone) is conjugated with naphthazarin (5,8-dihydroxynaphthoquinone).
\end{abstract}

In screening for new antibiotics produced by Micromonospora, we found that a new strain for which the name Micromonospora verruculosa sp. nov. ${ }^{1)}$ was proposed, produced a new antibiotic complex named M-92 which was exceedingly active against some Gram-positive and Gram-negative bacteria. M-92 complex was extracted with acidic methanol from the mycelial cake. Crude complex was then separated into six major components designated VA-2, BA-4, BA-5, BN-1, BN-2 and BN-3 by silica gel $\mathrm{H}$ column chromatography. They were acidic or neutral in nature and blue or violet in color. This paper deals with the isolation and purification of the M-92 components and their physicochemical properties. Biological properties of these components will be reported in the succeeding paper ${ }^{2)}$. The structural elucidation of these components is now under way.

\section{Isolation and Purification}

Isolation of a crude powder of the M-92 complex was achieved as shown in Chart 1 . Thus, $24 \mathrm{~g}$ of a crude powder of the M-92 complex was obtained from 1,000 liters of fermentation broth.

According to the procedures shown in Chart 2, the chloroform solution of the M-92 complex was separated into A group (acidic substances) which is soluble in alkaline water $\left(\mathrm{Na}_{2} \mathrm{CO}_{3}, \mathrm{pH}\right.$ 8.5) and $\mathrm{N}$ group (weakly acidic or neutral substances) which is insoluble. The A group components in the chloroform layer were washed with water and then evaporated to dryness in vacuo. Thus, $6.5 \mathrm{~g}$ of a crude powder of the A group components and $10.4 \mathrm{~g}$ of a crude powder of the $\mathrm{N}$ group components were obtained from $20 \mathrm{~g}$ of crude M-92 complex.

The isolation and purification of the A group components were carried out by silica gel $\mathrm{H}$ [Merck, impregnated with $0.5 \mathrm{M}$ McIlvain buffer ( $\mathrm{pH}$ 5)] column chromatography as shown in Chart 3 . Then, 
Chart 1. Extraction of M-92 complex.

Fermentation whole broth (1,000 liters)

adjusted to $\mathrm{pH} 2$ with $6 \mathrm{~N} \mathrm{HCl}$

added talc $(1 \mathrm{~kg})$ and Celite $545(2 \mathrm{~kg})$

stirred for 30 minutes, filtered

Mycelial cake

extracted with 100 liters $(\times 2)$ of acidic methanol (adjusted to $\mathrm{pH} 2$ with $6 \mathrm{~N} \mathrm{HCl}$ )

Methanol extract (160 liters)

adjusted to $\mathrm{pH} 10$ with $6 \mathrm{~N} \mathrm{NaOH}$

Cake added Celite $545(1.6 \mathrm{~kg})$ filtered

suspended in 14 liters of water

adjusted to $\mathrm{pH} 2$ with $6 \mathrm{~N} \mathrm{HCl}$

extracted with 7 liters $(\times 2)$ of chloroform

Chloroform layer (13 liters)

washed with 5 liters of water and evaporated

Crude oil (130 g)

added 1.5 liters of $n$-hexane

Precipitate

dried in vacuo

Crude powder of M-92 complex (24 g) the A group components were separated into the VA group components which are acidic violet substances, and BA-4 and BA-5 components which are blue and acidic. Further, the VA group components were separated to VA-1, VA-2 and VA-4. Thus, $2 \mathrm{mg}$ of VA-1, $250 \mathrm{mg}$ of VA-2, $1 \mathrm{mg}$ of VA-4, $2.45 \mathrm{~g}$ of BA-4 and $2.54 \mathrm{~g}$ of BA-5 were obtained from $6 \mathrm{~g}$ of crude powder of the A group components.

The $\mathrm{N}$ group components were isolated and purified in similar ways to the A group components as shown in Chart 4. Then, the $\mathrm{N}$ group components were separated into components $\mathrm{BN}$ 1, BN-2 and BN-3 which are blue and weakly acidic, and VN-3 which is violet and weakly acidic. In this manner, $0.73 \mathrm{~g}$ of $\mathrm{BN}-1,1.0 \mathrm{~g}$ of $\mathrm{BN}-2,4.8 \mathrm{~g}$ of $\mathrm{BN}-3$ and $1 \mathrm{mg}$ of $\mathrm{VN}-3$ were

Chart 2. Isolation of $\mathrm{A}$ and $\mathrm{N}$ group components.

Crude powder of M-92 complex ( $20 \mathrm{~g}$ )

dissolved in 3 liters of chloroform added 1.5 liters of $1 \% \mathrm{Na}_{2} \mathrm{CO}_{3}$ solution stirred

Chloroform layer

washed with 1 liter of water evaporated to dryness

Crude powder of $\mathrm{N}$ group components (10.4 g)

\author{
Aqueous layer \\ adjusted to $\mathrm{pH} 2$ with $6 \mathrm{~N} \mathrm{HCl}$ \\ added 1 liter of chloroform \\ Chloroform layer \\ evaporated to dryness \\ Crude powder of A group components (6.5 g)
}

Chart 3. Isolation and purification of A group components.

Crude powder of A group components $(6 \mathrm{~g})$

dissolved in MeOAc

Silica gel H column $(1.2 \mathrm{~kg}, 90 \times 7.5 \mathrm{~cm}$ diameter $)$

developed with $\mathrm{MeOAc}$ saturated with $\mathrm{H}_{2} \mathrm{O}$ and collected $100 \mathrm{ml}$ fractions

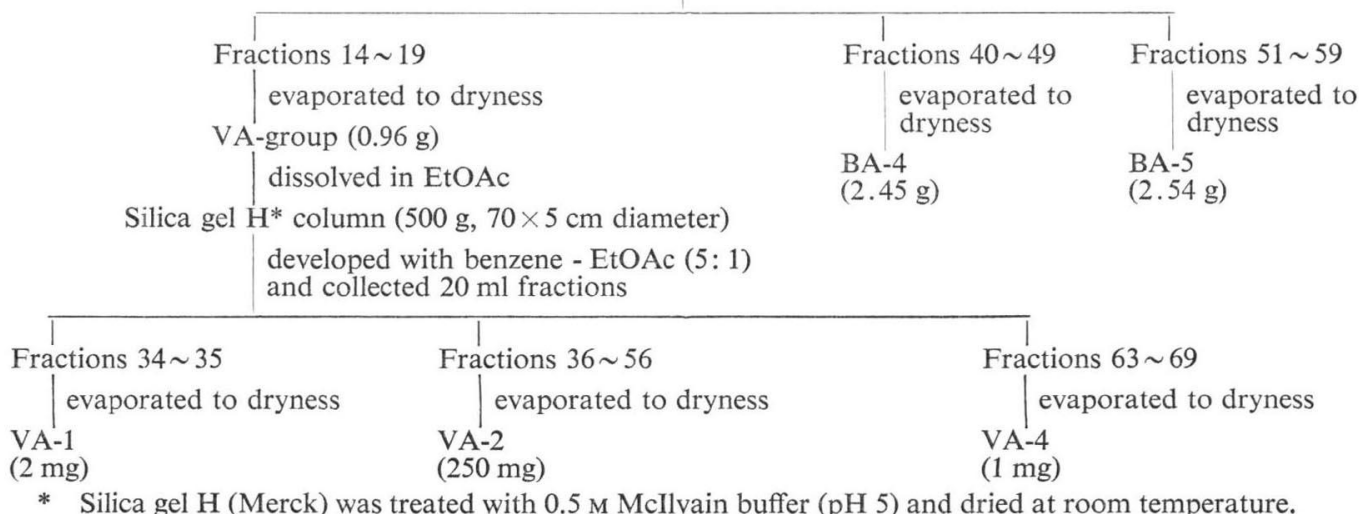

* Silica gel H (Merck) was treated with $0.5 \mathrm{M} \mathrm{Mcllvain} \mathrm{buffer} \mathrm{(pH} \mathrm{5)} \mathrm{and} \mathrm{dried} \mathrm{at} \mathrm{room} \mathrm{temperature.}$ 
Chart 4. Isolation and purification of $\mathrm{N}$ group components.

Crude powder of $\mathrm{N}$ group components $(10 \mathrm{~g})$

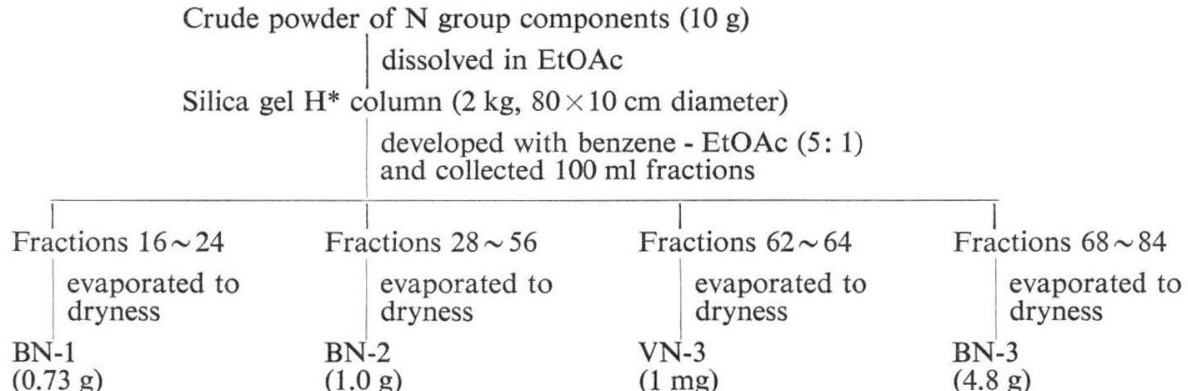

* Silica gel H (Merck) was treated with $0.5 \mathrm{M}$ McIlvain buffer (pH 5) and dried at room temperature.

Table 1. Physicochemical properties of M-92 components.

\begin{tabular}{|c|c|c|c|c|c|c|c|}
\hline & & VA-2 & BA-4 & BA-5 & BN-1 & $\mathrm{BN}-2$ & $\mathrm{BN}-3$ \\
\hline \multicolumn{2}{|c|}{ Elementary analysis } & $\begin{array}{r}66.59 \\
3.29 \\
2.68\end{array}$ & $\begin{array}{r}68.69 \\
7.02 \\
2.10\end{array}$ & $\begin{array}{r}66.12 \\
6.72 \\
2.01\end{array}$ & $\begin{array}{r}62.12 \\
5.25 \\
2.02\end{array}$ & $\begin{array}{r}62.92 \\
4.54 \\
2.60\end{array}$ & $\begin{array}{r}65.79 \\
4.44 \\
2.65\end{array}$ \\
\hline \multicolumn{2}{|l|}{$\mathrm{MP}\left({ }^{\circ} \mathrm{C}\right)$} & 250 & $251 \sim 254$ & $185 \sim 190$ & $146 \sim 151$ & $249 \sim 252$ & 300 \\
\hline \multicolumn{2}{|c|}{$[\alpha]_{\mathrm{D}}^{26}(c 0.01, \mathrm{MeOH})$} & $\begin{array}{c}+500^{\circ} \\
(\mathrm{MeOH}+ \\
\text { dimethyl- } \\
\text { formamide })\end{array}$ & $-980^{\circ}$ & $-1040^{\circ}$ & $-980^{\circ}$ & $-1160^{\circ}$ & $-620^{\circ}$ \\
\hline \multicolumn{2}{|c|}{$\mathrm{UV} \lambda_{\max }^{\mathrm{MeOH}} \mathrm{nm}\left(\mathrm{E}_{1 \mathrm{~cm}}^{1 \%}\right)$} & $\begin{array}{l}242(465) \\
290 \mathrm{sh}(110) \\
580(189.5) \\
610(182)\end{array}$ & $\begin{array}{l}243(635) \\
290 \mathrm{sh}(112) \\
590(152) \\
640(267)\end{array}$ & $\begin{array}{c}245.5(367.5) \\
590(152) \\
640(152)\end{array}$ & $\begin{array}{l}242(352.5) \\
277 \mathrm{sh}(210) \\
590(171) \\
640(170)\end{array}$ & $\begin{array}{c}243.5(577.5) \\
289 \mathrm{sh}(140) \\
590(247.5) \\
640(244.5)\end{array}$ & $\begin{array}{l}243(820) \\
290 \mathrm{sh}(130) \\
590(195) \\
640(193.5)\end{array}$ \\
\hline \multicolumn{2}{|c|}{$\begin{array}{l}\lambda_{\max }^{0.1 \mathrm{NaOH}-\mathrm{MeOH}} \mathrm{nm} \\
\quad\left(\mathrm{E}_{1 \mathrm{~cm}}^{1 \%}\right)\end{array}$} & $\begin{array}{l}248(457.5) \\
290 \mathrm{sh}(110) \\
610(200) \\
650(217.5)\end{array}$ & $\begin{array}{c}245.5(635) \\
290 \operatorname{sh}(132.5) \\
615(279) \\
660(635)\end{array}$ & $\begin{array}{l}245.5(442.5) \\
290 \operatorname{sh}(185) \\
615(202) \\
660(240)\end{array}$ & $\begin{array}{l}244.5(395) \\
330(202.5) \\
615(178) \\
660(210)\end{array}$ & $\begin{array}{l}246(602) \\
287 \mathrm{sh}(140) \\
615(264) \\
660(316.5)\end{array}$ & $\begin{array}{l}245.5(821) \\
290 \text { sh }(150) \\
615(204) \\
660(240)\end{array}$ \\
\hline \multicolumn{2}{|l|}{ IR $\nu_{\max }^{\text {Nujol }} \mathrm{cm}^{-1}$} & $\begin{array}{l}3300,1660 \\
1630,1585\end{array}$ & $\begin{array}{l}3450,3300 \\
1730,1640 \\
1600,1580\end{array}$ & $\begin{array}{l}3500,3320 \\
1735,1645 \\
1600,1590\end{array}$ & $\begin{array}{l}3200,1675 \\
1650,1605 \\
1585\end{array}$ & $\begin{array}{l}3450,1690, \\
1670,1600 \\
1585\end{array}$ & $\begin{array}{l}3450,3300, \\
1730,1640, \\
1600,1580\end{array}$ \\
\hline \multirow[t]{3}{*}{ Solubility } & Soluble & $\begin{array}{l}\text { Dioxane, } \\
\text { dimethyl- } \\
\text { formamide, } \\
\text { alkaline } \\
\text { water }\end{array}$ & $\begin{array}{l}\text { Ethylacetate, } \\
\text { dioxane, } \\
\text { alkaline } \\
\text { water }\end{array}$ & $\begin{array}{l}\text { Similar to } \\
\text { BA-4 }\end{array}$ & $\begin{array}{l}\text { Acetone, } \\
\text { chloroform, } \\
\text { ethyl acetate }\end{array}$ & $\begin{array}{l}\text { Similar to } \\
\text { BN-1 }\end{array}$ & $\begin{array}{l}\text { Similar to } \\
\text { BN-1 }\end{array}$ \\
\hline & $\begin{array}{l}\text { Slightly } \\
\text { soluble }\end{array}$ & $\begin{array}{l}\text { Acetone, } \\
\text { ethyl acetate }\end{array}$ & $\begin{array}{l}\text { Acetone, } \\
\text { chloroform, } \\
\text { methanol }\end{array}$ & " & $\begin{array}{l}\text { Methanol, } \\
\text { ether }\end{array}$ & " & " \\
\hline & Insoluble & $\begin{array}{l}\text { Ether, } \\
\text { hexane }\end{array}$ & $\begin{array}{l}\text { Ether, } \\
\text { hexane, } \\
\text { water }\end{array}$ & " & $\begin{array}{l}\text { Hexane, } \\
\text { water }\end{array}$ & $"$ & " \\
\hline $\begin{array}{l}\text { Rf value on } \\
\text { silica gel* TLC }\end{array}$ & $\begin{array}{l}a^{* *} \\
\mathrm{~b}\end{array}$ & $\begin{array}{l}0.50 \\
0.54\end{array}$ & $\begin{array}{l}0.15 \\
0.34\end{array}$ & $\begin{array}{l}0.09 \\
0.18\end{array}$ & $\begin{array}{l}0.58 \\
0.89\end{array}$ & $\begin{array}{l}0.41 \\
0.57\end{array}$ & $\begin{array}{l}0.26 \\
0.76\end{array}$ \\
\hline
\end{tabular}

* Silica gel H plates (Merck) were treated with $0.5 \mathrm{M}$ McIlvain buffer (pH 5) and dried at room temperature and activated for 1 hour at $110^{\circ} \mathrm{C}$.

** Solvent system a: Benzene - ethyl acetate $(5: 1)$. b: Chloroform - methanol (19:1).

obtained from $10 \mathrm{~g}$ of crude powder of the $\mathrm{N}$ group components.

\section{Physicochemical Properties}

The physicochemical properties and the Rf values on TLC of these six major components are listed 
in Table 1. These components, obtained as reddish violet to blue amorphous powder, are acidic or weakly acidic in nature. These antibiotics gave a reddish brown color with conc. $\mathrm{H}_{2} \mathrm{SO}_{4}$, and reddish orange color with formic acid and zinc powder, but were negative to the ninhydrin test. The IR spectra of M-92 components showed the chelated $\mathrm{OH}$ band at around $3300 \mathrm{~cm}^{-1}$ and the hydrogen bonded $\mathrm{C}=\mathrm{O}$ band at $1630 \sim 1640 \mathrm{~cm}^{-1}$. The UV spectra exhibited characteristic peaks in common to all components, suggesting that their chromophores may be the same or very closely related to one another.

The acidic (A) group components of M-92 did not give molecular ions on EI-mass spectroscopy, but $\mathrm{BN}-3$ afforded the molecular ion peak at $m / z 529.1366\left(\mathrm{C}_{29} \mathrm{H}_{23} \mathrm{NO}_{9}, \Delta-0.4 \mathrm{mmu}\right)$ and fragment ions at $m / z 514\left(\mathrm{M}-\mathrm{CH}_{3}\right), 501(\mathrm{M}-\mathrm{CO}), 498,497\left(\mathrm{M}-\mathrm{CH}_{3} \mathrm{O}, \mathrm{M}-\mathrm{CH}_{3} \mathrm{OH}\right)$. PMR spectrum of $\mathrm{BN}-3$ $\left(\mathrm{CDCl}_{3}\right)$ showed three methyl signals at $\delta 1.27$ (d), 1.36 (s) and 3.57 (s) and three chelated phenolic hydroxyl groups as sharp singlets at $\delta 12.03,12.38$ and 12.78. These singlets vanished after the addition of $\mathrm{CD}_{3} \mathrm{OD}$, so that these hydroxyl groups must be in the peri-positions to the quinone carbonyls. The spectrum showed also five aromatic portons but not quinoid protons ${ }^{3)}$. These results suggested that M-92 consisted of chromophores built up from conjugated juglone (5-hydroxynaphthoquinone) and naphthazarin (5,8-dihydroxynaphthoquinone) like actinorhodins $\mathrm{s}^{4,5)}$. Moreover, M-92 components are different from any of the known antibiotics in their physicochemical properties. M-92 complex is thus concluded to be new antibiotic.

\section{Acknowledgements}

The authors wish to thank Professor M. Suzuki, Faculty of Pharmacy, Meijo University, and Dr. N. NAGAHAMA, Japan Upjohn Research Laboratories, for valuable discussions. We are also greatly indebted to Dr. T. OKUDA and Dr. M. KAWANISHI, the former and present directors of this Research Laboratory, for their advice and encouragement throughout this work.

\section{References}

1) Tani, K.; N. Matsuzawa, S. Yano \& T. Yamaguchi: Studies on a new antibiotic M-92 produced by Micromonospora. I. Taxonomy of M-92 producing Micromonospora and antibiotic production therefrom. J. Antibiotics 35: 1430 1436, 1982

2) Tani, K.; Y. Arai \& T. Yamaguchi: Studies on a new antibiotic M-92 produced by Micromonospora. III. Biological activities. J. Antibiotics 35: 1441 1447, 1982

3) Moore, R. E. \& P. J. Scheuer: Nuclear magnetic resonance spectra of substituted naphthoquinones. Influence of substituents on tautomerism, anisotropy and stereochemistry in the naphthazarin system. J. Org. Chem. 31: 3272 3283, 1966

4) Brockmann, H. \& A. Zeeck: Zur Tautomerie des Actinorhodins und 2,2'-Bisnaphthazarins. Chem. Ber. 101: $4221 \sim 4229,1968$

5) Brockmann, H.; H. Greve \& W. Wakdmüller: Dimerisierung und Cyclo-Trimerisierung von Naphthazarin und 5,6,7,8-Tetrahydro-Chinizarin. Chem. Ber. 104: 1436 1454, 1971 